\title{
REVIEW
}

\section{Balantidium coli INFECTION, IMMUNE STATUS AND COMORBIDITIES: LITERATURE REVIEW}

\author{
Amanda Silva de Oliveira ${ }^{1 \S}$, Cesar Gómez-Hernández ${ }^{2 \S}$ and Karine Rezende- \\ Oliveira ${ }^{1}$
}

\section{ABSTRACT}

Balantidiasis, a disease caused by the ciliated protozoan Balantidium coli, mainly infects the large intestine and may present intestinal spread. The purpose of this literature review was to study the infection by $B$. coli and comorbidities to identify the factors that can contribute to the establishment of the disease. In this review, we attempt to explore and describe the various comorbidities associated with $B$. coli infection. We reviewed the literature based on comorbidities with a focus on the association with $B$. coli infection. The primary platforms targeted were PubMed, LILACS, SciELO and Google Scholar. Studies published between 1990 and 2020 in Portuguese, English, and Spanish were considered. The comorbidities reported in the papers were diverse, associating infection by $B$. coli with the immunosuppression that they generate. The intestinal microbiota may also play an important role, because when dysbiosis is present, its composition and structure are affected, which may enable the invasion of the mucosa. The review shows that the presence of the parasite and establishment of balantidiasis can influence in the clinical stage of chronic and autoimmune diseases, considering the modulation of the immune response in presence of $B$. coli.

KEY WORDS: Balantidium coli; autoimmunity; balantidiosis; comorbidities; immunodepression.

\section{INTRODUCTION}

Balantidium coli is a ciliated protozoan, capable of infecting a variety of mammals (Zaman, 1964; Nakauchi,1999; Gerald \& Bailey, 2002; Fletcher et al., 2012; Ahmed et al., 2019; Bianchi et al., 2019; Zhao et al., 2020). However, pigs are considered the main hosts (Hernández et al., 1993; Pomajbıkova et al., 2013). The protozoan can also infect, causing balantidiasis (Solaymanimohammadi et al., 2005).

1. Federal University of Uberlândia, Institute of Exact and Natural Sciences of Pontal, Biomedical Sciences Laboratory, Ituiutaba, Minas Gerais, Brazil.

2. Federal University of Triângulo Mineiro, Immunology Laboratory, Uberaba, Minas Gerais, Brazil.

$\S$ Contributed equally to this work

Amanda Silva de Oliveira: https://orcid.org/0000-0003-4403-8580; Cesar Gómez-Hernández: https://orcid.org/0000-0003-27928485; Karine Rezende-Oliveira: https://orcid.org/0000-0002-1220-6052

Corresponding author: César Gómez-Hernández. E-mail: cesar_cgh@hotmail.com

Received for publication: 20/10/2021. Reviewed: 12/1/2022. Accepted: 13/1/2022. 
The infectious form, dispersed in the environment, is a spherical or slightly ovoid cyst presenting a thick protective wall, and measuring approximately $40 \mu \mathrm{m}$ to $70 \mu \mathrm{m}$ in diameter (Fletcher et al., 2012; Ponce-Gordo et al., 2011; Ponce-Gordo \& Jirků-Pomajbíková, 2017). The trophozoites measuring approximately $30 \mu \mathrm{m}$ to $200 \mu \mathrm{m}$ in length are ovoid shaped and covered by somatic cilia, allowing a rotating movement and facilitating locomotion (Fletcher et al., 2012; Farthing \& Kelly, 2005; Schuster \& RamirezAvila, 2008). In the anterior portion, there is an oral apparatus characterized by a depression where the cytostome covered by oral lashes can be seen. In an opening in the posterior region is the cytopigium (excretory structure) (PonceGordo et al., 2011; Ponce-Gordo \& Jirků-Pomajbíková, 2017; Nilles-bije \& Rivera, 2010).

Human infections by $B$. coli generally occur in rural and agrarian areas where individuals have direct contact with pigs, however, the lack of personal and environmental hygiene in some places predisposes human infection (Schuster \& Ramirez-Avila, 2008). Cysts can contaminate water and food, and when ingested they reach the large intestine, where excision occurs. The trophozoites then develop and remain active in the intestinal lumen by feeding or, in some cases, promoting ulcerations in the intestinal mucosa by releasing the enzyme hyaluronidase, which degrades the important hyaluronic acid in the epithelium. The trophozoites that remain in the lumen encyst and are excreted along with feces (Schuster \& Visvesvara, 2004; Hechenbleikner \& Mcquade, 2015).

In general, balantidiasis is asymptomatic, but when it presents clinical manifestations, these are characterized by dysentery, similar to that of the amoebiasis caused by Entamoeba histolytica, including diarrhea that can be mucous-bloody, abdominal cramps, fever, nausea, and vomiting (Parija \& Giri, 2012; Kumar et al., 2016). More serious disease complications often affect individuals with weakened immune systems (Schuster \& Ramirez-Avila, 2008). The presence of ulcers in the intestinal mucosa allows the invasion of trophozoites, in addition to the production of the enzyme hyaluronidase by the protozoan, which aggravates the ulceration, and may spread to other organs such as lungs, liver, vermiform appendix, and bladder (Dodd, 1991; Anargyrou et al., 2003; Karuna \& Khadanga, 2014; Kapur et al., 2016). In these cases, the individual's immunological condition is crucial, as reports indicate that balantidiasis, especially extra-intestinal, occurs in immunologically weakened people affected by other comorbidities, and in cases related to malnutrition or alcoholism (Schuster \& Ramirez-Avila, 2008; Schuster \& Visvesvara, 2004; Vasilakopoulou et al., 2003).

Although there are published studies on $B$. coli infection in humans, research concerning pathogenesis and mechanisms of infection in immunologically compromised individuals are scarce. Based on this information, the purpose of this literature review was to carry out a bibliographic study of 
human infection by $B$. coli and the relationship between the immunological conditions of an infected individual and comorbidities present to identify the host factors that may be associated with the establishment of the disease.

\section{MATERIAL AND METHODS}

A bibliographic review was carried out, using the electronic platforms PubMed, Latin American and Caribbean Literature in Health Sciences (LILACS), Scientific Electronic Library Online (SciELO), and Google Scholar for data collection (Figure).

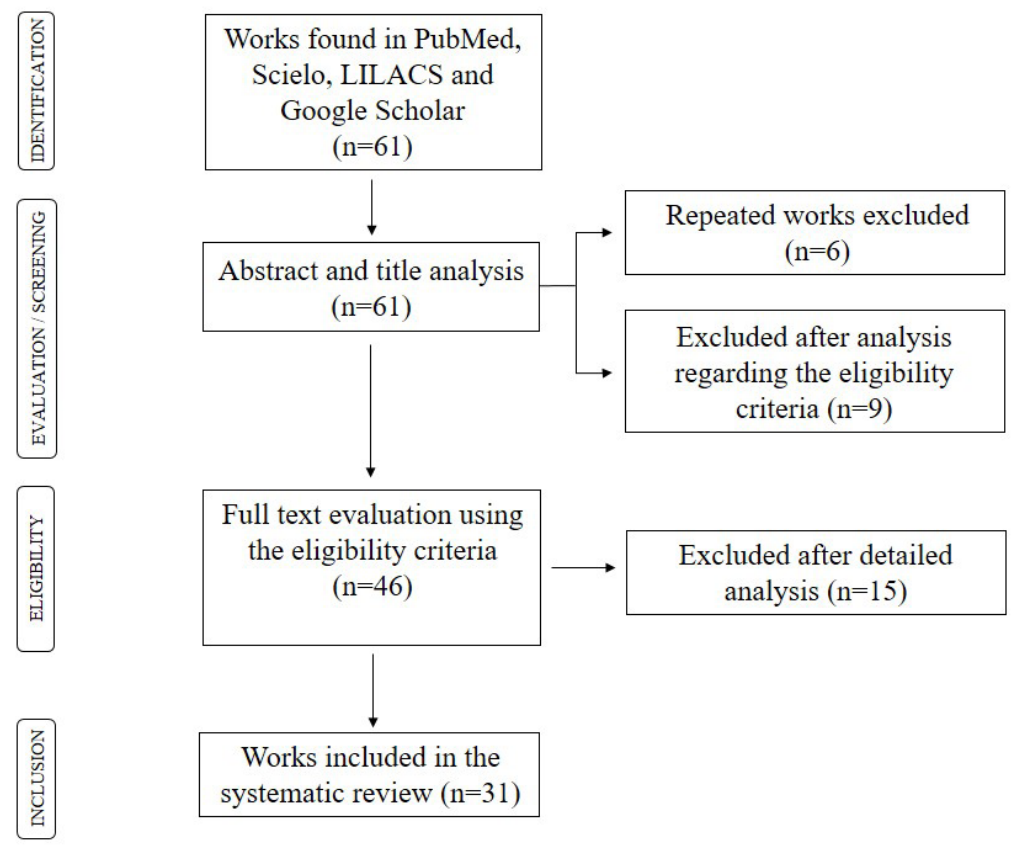

Figure. Flowchart of the selection of works published from 1990 to 2020 relating Balantidium coli infection to comorbidities

In the research, the descriptors DeCS/MeSH "Balantidium coli infection" and "Balantidiasis" were associated with the Boolean operator "AND" followed by the descriptors for comorbidities and infection site "Crohn Disease", "Diabetes mellitus", "Cancer", "Immunosuppression", "Systemic Lupus Erythematosus", "HIV", "Psoriasis", "Lung", "Liver", "Urinary Tract", and "Intestines". The research was conducted in English, Portuguese, and Spanish. 
For inclusion criteria, the following were considered: case reports, cross-sectional, observational studies, and other scientific papers, published in Portuguese, English or Spanish from 1990 to 2020, that considered B. coli infection associated with comorbidities.

For exclusion criteria, the following were dismissed: papers that did not address infection by the parasite, that did not present the involvement of comorbidities and that were published in other languages or before 1990 .

Initially, paper selection was performed by reading the titles and abstracts, later by reading the complete report and, finally, by discarding those that did not fit the inclusion criteria. In addition, we searched for reference lists of studies, which provided other studies in order to include the largest number of articles on the topic.

\section{RESULTS}

The purpose of this review was clarify the relationship between individuals who acquire $B$. coli infection and their comorbidities, in order to understand the immunological factors involved in this interaction. The literature on the subject is limited and there are no other reports addressing this interaction.

Regarding the frequency of events indicating a relationship between $B$. coli infection and comorbidities, the presence of the Human Immunodeficiency Virus (HIV) was mentioned in 10 studies (32.3\%), followed by cancer ( 5 studies - 16.1\%), diabetes mellitus (DM) (5 studies - 16.1\%), alcoholism (4 studies $12.9 \%$ ), renal failure (2 studies - 6.5\%), chronic obstructive pulmonary disease (COPD) (2 studies - 6.5\%), pemphigus vulgaris (1 study - 3.2\%), psoriasis (1 study - 3.2\%), and systemic lupus erythematosus (SLE) (1 study - 3.2\%) (Table).

Regarding the infection site, the most prevalent was intestinal balantidiasis (16 studies - 51.6\%), followed by urinary (seven studies - 22.6\%) and pulmonary (five studies $-16.1 \%$ ) balantidiasis. Other infection sites were reported, such as liver (1 study -3.2\%), peritoneum (1 study - 3.2\%), and spine (1 study - 3.2\%) (Table).

India presented the highest number of published papers on the topic involving B. coli with seven (22.6\%) studies, followed by Brazil and Nigeria with three $(9.7 \%)$ publications each, and Greece and Venezuela, each with two articles (6.4\%) (Table). 


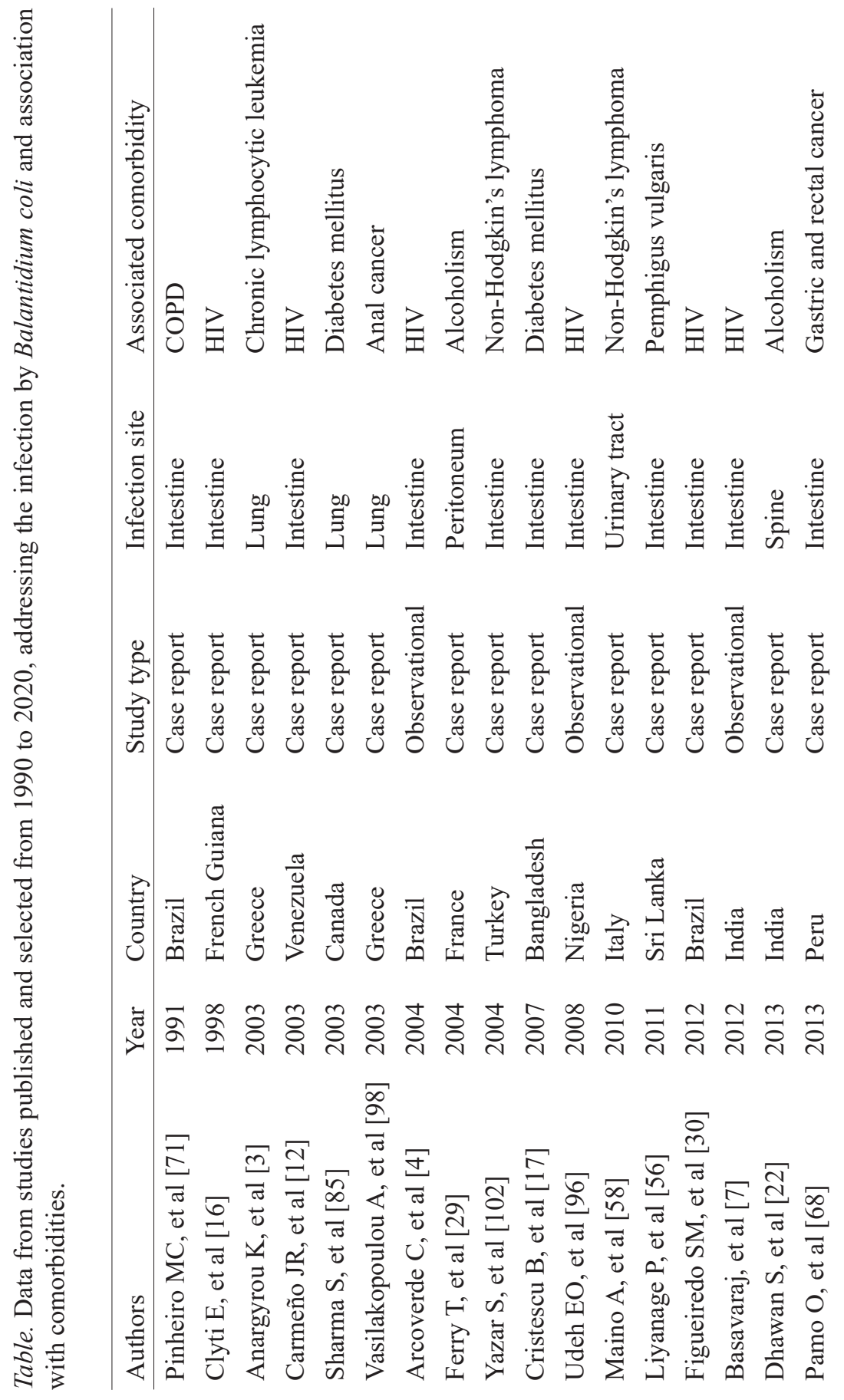




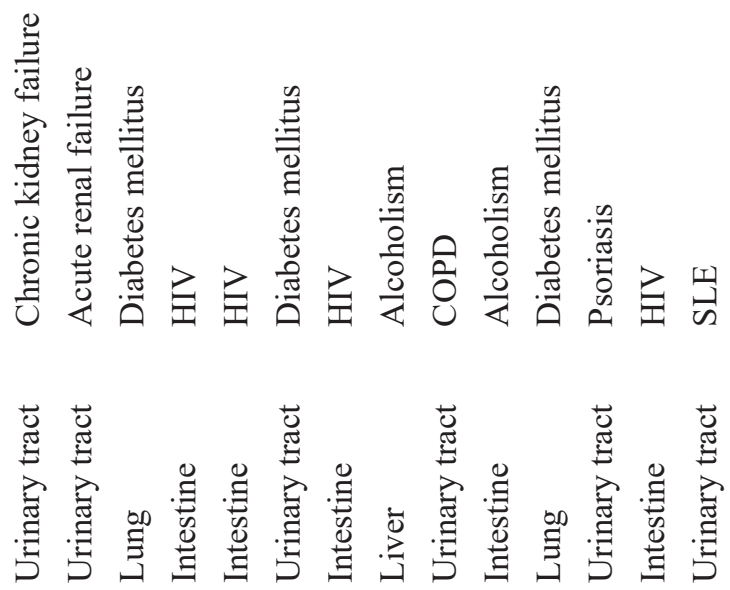

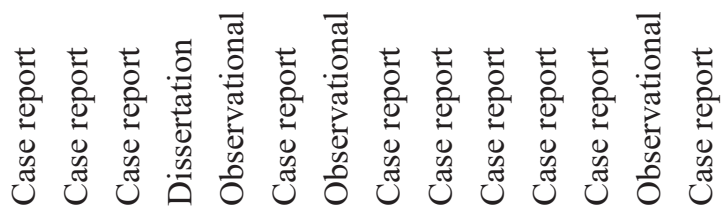

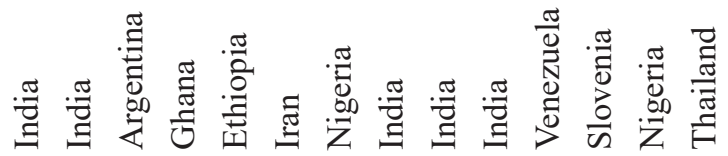
芦

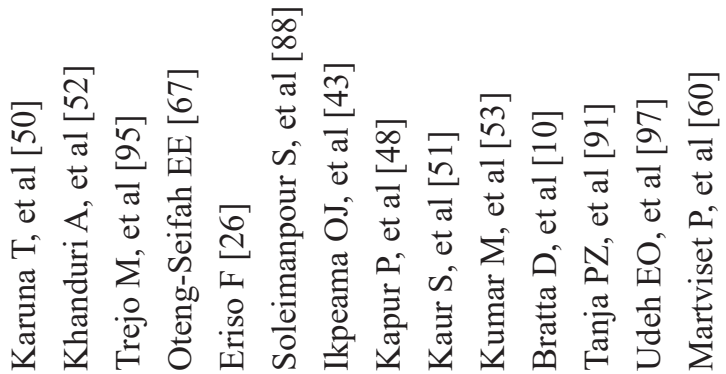




\section{DISCUSSION}

\section{Human Immunodeficiency Virus (HIV)}

Three of the $10(30 \%)$ studies regarding HIV positive patients are case reports. The report by Clyti et al. (1998) was the first case described in the literature regarding an HIV patient in French Guiana, who developed balantidian dysentery, and the study by Carmeño et al. (2003) was the first case of a patient with HIV described in Venezuela. According to these authors, the infection was aggravated mainly, by the immunosuppressive characteristic of the disease.

Infection by the HIV virus directly influences CD4+ T cell functions, modulates $\mathrm{CD} 4+$ and $\mathrm{CD} 8+\mathrm{T}$ responses, damages specific antigen responses and compromises the production of cytokines by natural killer cells (NK), necessary functions in the response to infections (Janssen et al., 2015; Cerveja et al., 2017).

The combination of different antiviral agents for antiretroviral therapy (ART) was determined to decrease the viral load and thus improve the patient's immune system due to an increase in the CD4+ T count, reducing morbidity and mortality (Pau, 2014; Souza et al., 2019). However, adverse effects of short or long-term gastrointestinal infections, such as diarrhea, nausea, and abdominal pain, can arise at the same time as infections by opportunistic enteric pathogens (Montessori et al., 2004).

Figueiredo et al. (2012) describe the first case in Brazil of an HIVpositive patient on combined antiretroviral therapy with intestinal balantidiosis. The clinical manifestations of balantidiosis in this patient coincided with the presence of side effects caused by ART, a fact that deserves attention by health professionals who treat this type of patient.

Research addressing HIV balantidiosis consisted of observational studies, with a view to investigate the prevalence of intestinal parasites in HIVpositive patients treated in hospitals. Four papers found a higher prevalence of infection by B. coli, as follows. The report by Basavaraj et al. (2012) investigated parasitic infections in eight children admitted to a hospital in the city of Hubli, in India, where $B$. coli was the most prevalent intestinal parasite $(13.3 \%)$, with $5(62.5 \%)$ children with severe immunodeficiency and $1(12.5 \%)$ with mild immunodeficiency. The study by Udeh et al. (2019), in Makurdi, Nigeria, with $B$. coli prevalence in $10(3.8 \%)$ HIV-positive patients undergoing treatment (ART), of which six $(60 \%)$ presented a CD4 + T lymphocyte count $<350$ cells/uL and four $(40 \%)$ presented $<500$ cells/uL.

The CD4+T lymphocyte count indicating a state of severe immunosuppression and involvement by opportunistic infections is generally below 200 cells/uL. However, counts below 350 cells/uL, in some studies, already indicate an increased risk of infections by opportunistic microorganisms (Udeh et al., 2019). 
In a study carried out in Nigeria, Ikpeama et al. (2016) investigated the prevalence of intestinal parasites in HIV-positive individuals and identified infection by $B$. coli in $10(3.4 \%)$ patients in hospitals in Sokoto. Checking the prevalence of opportunistic intestinal parasites, Eriso (2015) found 19 (2.68\%) HIV-positive patients infected with $B$. coli in Ethiopian hospitals. The rest of the selected studies identified only one patient infected by $B$. coli in the search for intestinal parasitic infections (Udeh et al., 2019; Arcoverde et al., 2004; Udeh, et al., 2008; Kurts, et al., 2013; Oteng-Seifah, 2015).

All selected reports that include HIV-positive patients infected with $B$. coli show clinical manifestations of intestinal balantidiosis. As is known, HIV patients present a greater chance of opportunistic intestinal parasitic infections, caused by protozoa (extra and intracellular) and helminths. The severe diarrhea caused in these individuals negatively influences the defense mechanisms of the gastrointestinal mucosa, such as the production of IgA antibodies and local immune cells, making them more susceptible to opportunistic infections (Adamu et al., 2013). Among the protozoa, the most reported in the studies include Cryptosporidium spp., Blastocystis spp., Isospora belli, Giardia lamblia and Entamoeba histolytica / E. dispar (Adamu et al., 2013; Bachur, et al., 2008; Nissapatorn \& Sawangjaroen, 2011; Taye et al., 2014). However, the number of articles reporting a correlation between $B$. coli infections and HIV-patients is significant, meaning that it is also a protozoan to be considered in intestinal infections in this population.

\section{Cancer}

Two of the reports relating balantidiosis and the presence of cancer or an infection with pulmonary involvement occurred in Greece. Anargyrou et al. (2003) report B. coli infection in a patient with chronic lymphocytic leukemia (CLL-B). CLL is a neoplasm characterized by the abnormal accumulation, in the case of the patient in question, of type B lymphocytes in the peripheral blood, bone marrow, and lymphoid organs (Gonçalves et al., 2009; Marrero, 2019). The patient was in the Rai 0 stage, which indicates an early stage of the disease, but presented cervical, axial and inguinal lymphodenopathy, which is an increase in lymph nodes, and was, therefore, immunocompromised, due also to long-term use of corticosteroids and chemotherapic treatment, impairing lymphocyte function (Anargyrou et al., 2003).

Vasilakopoulou et al. (2003) portray the fatal case of a patient with anal cancer, in addition to other associated comorbidities, such as diabetes mellitus and arterial hypertension, presenting impairment of the immune system due to chemotherapy and radiotherapy sessions, which was probably the cause of the exacerbation of pulmonary balantidiasis and consequent death. The study of Pamo et al. (2013) reports four cases of patients infected with intestinal B. coli seen in hospitals in Lima, Peru. Among these, one patient had gastric cancer, and another was diagnosed with rectal carcinoma. 
Chemotherapy and radiotherapy treatments can cause a series of clinical complications to the patient, immunosuppression being the most recurrent and interfering with effective immune response mechanisms, such as $\mathrm{T}$ and $\mathrm{B}$ lymphocytes, NK cells, dendritic cells and macrophages. In addition, it causes suppression of the bone marrow, which recomposes blood cells, including components of the immune system, which can impair the fight against infections, mainly by opportunistic agents (Sawada et al., 2009; Silva \& Márcio, 2011; Carvalho \& Villar, 2018). Estimates indicate that colorectal cancers are among the most aggressive and frequent, and the cause of high mortality, along with stomach cancer (Toychiev et al., 2018). Due to being in an immunocompromised state owing to neoplasia, cancer patients are susceptible to infections by parasites, including commensal and opportunistic intestinal protozoa (Jeske et al., 2018; Esteghamati et al., 2019; Mahmoudi et al., 2020).

The case reports of patients with non-Hodgkin's lymphoma, in Turkey and Italy, presented B. coli infection with intestinal and urinary involvement, respectively (Yazar et al., 2004; Maino et al., 2010). This type of lymphoma is a form of cancer originated in the lymphatic system, classified according to the type of cell affected, that is, T or B lymphocytes, the second being the cause of most infections (Rogers, 2006).

\section{Diabetes Mellitus (DM)}

Among the reports that include DM, three describe infection by $B$. coli resulting in pulmonary involvement. The studies by Trejo et al. (2014) and Bratta et al. (2018) portray the diagnosis of pneumonia caused by B. coli in patients with a history of DM in addition to arterial hypertension. In the first case, the patient's DM was poorly controlled. Sharma \& Harding (2003) also report the case of a farmer with a history of insulin-dependent DM who presented a necrotizing lung infection caused by the protozoan. Two other cases involving DM report the case of intestinal and urinary balantidiosis in Bangladesh and Iran, respectively (Cristescu, 2007; Soleimanpour et al., 2015).

$\mathrm{DM}$ is part of the group of chronic non-communicable diseases (CNCD), and it can be subdivided into DM type 1 (DM1) and type 2 (DM2). Both forms result in progressive loss of mass and/or function of pancreatic $\beta$ cells, leading to manifest hyperglycemia, which is harmful to the body (Eizirik et al., 2020). DM1 is characterized as an autoimmune disease in which the immune system attacks and destroys pancreatic $\beta$ cells. It is caused by environmental and genetic factors that have not yet been fully clarified; the latter usually associated with polymorphisms in the Human Leukocyte Antigen (HLA) molecules in the Major Histocompatibility Complex (MHC). Studies indicate the involvement of CD4 + and CD8 + T lymphocytes, with the release of chemokines and cytokines, macrophages, and specific autoantibodies produced by plasma cells in the autoimmune process in DM1. In DM2, there 
is impaired insulin secretion by pancreatic $\beta$ cells associated with insulin resistance, which can be related to individual lifestyle and the development of the disease (Eizirik et al., 2020; Ilonen et al., 2019).

In addition to the effects generated by autoimmunity, there are consequences regarding the immune dysfunction of DM as it is considered a chronic disease. Hyperglycemia has been seen to cause an increase in the virulence of some pathogens and, therefore, also increases the risk of infections in individuals with DM (Chovancová, 2019). In patients with DM, hypotheses have been raised regarding a decrease in the concentration of components in the complement system, such as the $\mathrm{C} 4$ molecule, disturbances in the secretion of cytokines and chemokines, and decreased phagocytic function of polymorphonuclear cells (Chovancová, 2019; Geerlings \& Hoepelman, 1999).

\section{Alcoholism}

Alcoholism is often mentioned as a factor that favors $B$. coli infection. Studies report $B$. coli peritonitis in France associated with patient alcoholism, hypertension, and moderate asthma (Ferry et al., 2004; Granier, 2004). Another three cases occurred in India. Dhawan et al. (2013) describe a rare case, in which $B$. coli caused cervical osteomyelitis in an alcoholic patient with a compromised nutritional status. This is supposed to be the first case of balantidiosis involving bone and the formation of a vertebral abscess. The report by Kumar et al. (2016) indicates an association between chronic alcoholism, intestinal infection by $B$. coli, and the patient's immunocompromised state due to anti-tuberculosis therapy six months earlier, which may have contributed to the establishment of the ciliate. The report by Kapur et al. (2016) portrays a case of a liver abscess in a patient, probably also associated with alcohol consumption. The effects of alcohol on the body have been studied for some time: changes in immune function due to frequent ingestion and negative implications depend on the intensity, consumption duration and type of drink (Diaz et al., 2002; Romeo \& Warnberg, 2010).

Among these alterations, the mechanisms that affect immunity may include leukocyte inability to migrate to the sites of injury and infection, interference in T and B lymphocyte functions, and reduction in their proliferation and of NK cells and monocytes/macrophages, in addition to affecting the balance and production of cytokines and antibodies (Romeo \& Warnberg, 2010; Sureshchandra et al., 2019). In a cytokine assay with alcoholics, an inflammatory response profile was noted, with serum concentrations mainly of TNF- $\alpha$, IL-6, IL-10, IL-12 and IL-13 (Gonzalez-Quintela et al., 2000; Daniluk et al., 2001). The imbalance of the intestinal microbiota was also probably due to the consumption of alcohol, which induces greater permeability of the epithelium enabling tissue invasion by pathogens (Bode \& Bode, 2003; Qamar et al., 2019). Therefore, high consumption of alcohol is considered an important 
immunomodulator and the cause of a certain degree of immunosuppression, also increasing infection incidence and an inadequate response to invasive agents (Diaz et al., 2002; Romeo \& Warnberg, 2010).

\section{Chronic Obstructive Pulmonary Disease (COPD)}

Pinheiro \& Lima (1991) and Kaur \& Gupta (2016) describe fatal reports of balantidiasis associated with COPD: the first with intestinal involvement, aggravated due to the critical nutritional state of the patient, the latter with urinary involvement in a patient under prolonged corticosteroid treatment. COPD presents several pulmonary manifestations, characterized by progressive airflow limitation, associated with chronic inflammation of the airways and/or pulmonary alveoli due to harmful particles or gases, causing narrowing of the airways, destruction of lung parenchyma and decrease in pulmonary compliance (Hattab et al., 2016; Rabe \& Watz, 2017).

Smoking is considered one of the main causes of COPD. Exposure to cigarette smoke influences inflammatory cell infiltration at the level of the airways, where local epithelial cells are destroyed. This destruction causes the release of intracellular molecules that are recognized by Toll-like receptors 2 and 4, and cytokines such as TNF- $\alpha$ and IL-8 are released and recruited to the $\mathrm{CD}$, macrophages and neutrophils, constituting the innate immune response (Rabe \& Watz, 2017; Decramer et al., 2012). CD4 + and $\mathrm{CD} 8+\mathrm{B}$ and $\mathrm{T}$ lymphocytes are activated via the presentation of released auto antigens, mediating the adaptive response. There is evidence of impaired immune regulation in COPD, due to a reduction in the Treg population and an increase in pro-inflammatory T helper 17 (Th17) in the lungs of these patients. However, the findings of some studies comparing the pulmonary and systemic immune response in COPD are controversial, yet it is believed that there is a small relationship between pulmonary and blood immune alterations (Rabe \& Watz, 2017; Decramer et al., 2012; Cruz et al., 2019).

COPD can manifest in different forms and intensities since it is a heterogeneous disease. In cases of disease exacerbation, anti-inflammatory treatment is indicated with inhaled or systemic corticosteroids, depending on the severity of the case. The aggravation is usually due to bacterial or viral infections, as well as a small percentage of non-pulmonary infections, which can be caused by other opportunistic agents that establish the infection more easily due to the immunocompromised state generated by COPD (Hattab et al., 2016; Decramer et al., 2012).

\section{Chronic Renal Failure}

Both studies that recorded cases of balantidiasis in patients with acute and chronic renal failure occurred in India (Karuna \& Khadanga, 
2014; Khanduri et al., 2014). Renal failure can occur acutely, with functional reduction of the kidney in hours or days. This refers to the decrease in the filtration rate, glomerular and/or urinary volume and electrolyte alterations, or in a chronic form as an abnormality in the structure and / or function of the kidney over an extended period of months or years (Weisbord \& Palevsky, 2006; Haller \& Strauer, 2012).

Due to the functional incapacity of the urinary system, renal failure is accompanied by uremia, that is, the increased presence of urea in the blood causing negative changes in patient immunity, since the kidneys have a fundamental role in the homeostasis of the immune system, removing cytokines and toxins from the body. The retention of these substances not eliminated efficiently activates innate immunity cells and further increases the production of other cytokines. In addition, there is a decrease in lymphocytes and NK cells, as well as functional alterations in phagocytosis and in the count of circulating neutrophils, macrophages and DCs, making the patient functionally immunocompromised and at risk of acquiring infections by different microorganisms, including urinary tract infections (Vaziri et al., 2012; Tecklenborg et al., 2018). Studies have evidenced the dysfunction of the intestinal barrier in the presence of uremia, resulting in the rupture of the epithelial junction and alteration in the permeability and composition of the microbiota (Kurts et al., 2013; Vaziri et al., 2012).

\section{Autoimmune Disease}

Three reports were found of balantidiasis in patients with autoimmune disease, a condition in which the immune system loses self-tolerance and body tissues and organs become the targets of the produced autoantibodies. Immunosuppressive drugs have become the standard treatment and are intended to contain the inflammation resulting from autoimmune diseases. However, patients using this type of therapy generally require higher doses of these drugs over time, increasing the toxicity and immunosuppression provided by their use (Proal \& Marshall, 2018).

Studies indicate, for instance, that corticosteroids inhibit the secretion of the $\mathrm{T}$ lymphocyte growth factor, interfere in the coding and production of various cytokines, such as IL-1, IL-2, IL-3, IL-4, IL- 5, IL-6, IL-8, IL-10, IL-13, TNF- $\alpha$ and IFN- $\gamma$, that is, generating a dysregulation in the immune function (Ashwell et al., 2000). Studies also indicate the association between autoimmune diseases in the generation of intestinal dysbiosis, with a decrease in commensal intestinal species and an increase in the proliferation of pathogenic species, resulting in alterations in the mucosa structure and loss of immune balance (Proal \& Marshall, 2018; Saadat et al., 2018). 
Liyanage et al. (2011) describe the case of a patient with common pemphigus, and diabetes with intestinal balantidiasis. Pemphigus vulgaris is a bullous disorder of the skin and mucous surfaces with an autoimmune characteristic. The target of circulating autoantibodies is mainly keratinocytes and desmoglein proteins 1 and 3, constituents of desmosomes, epithelial adhesion structures (Venugopal, 2011; Melchionda \& Harman, 2019). Individuals with pemphigus are known to be susceptible to infections due to their disease and long-term use of immunosuppressants. Although bacterial infections are common, other serious infections can occur due to unusual microorganisms (Liyanage et al., 2011).

In the pathogenesis of pemphigus, dermal layer NK cells stimulate CD4 + T cells to secrete pro-inflammatory cytokines IL-8, IL-6 and IFN- $\gamma$. The increase in the secretion of IL-17 and IL-23 has also been documented with a decrease in Treg cells, indicating the influence of Th1 and Th17-type responses to the disease and an unbalanced immune response (Das et al., 2019).

Tanja et al. (2018), in their article report another association between B. coli infection and autoimmune skin disease. The report is a case of urinary balantidiasis in a patient in Slovenia, with psoriasis, in addition to other comorbidities, such as hypertension, dyslipidemia, fatty liver disease, chronic gastritis, DM2, left breast carcinoma, urinary incontinence and gouty arthritis. According to the authors, considering the patient presented so many comorbidities, it is likely that all or most of them influenced in some way and more easily triggered the infection by the protozoan.

Psoriasis today is defined as an immune-mediated disease with an autoimmune characteristic. The excessive proliferation and abnormal differentiation of keratinocytes results in erythematous squamous plaques throughout the body, largely mediated by $\mathrm{T}$ cells and activation of innate immunity cells, such as macrophages and neutrophils, resulting in inflammation in the epidermal layers. The situation can be aggravated during treatment with immunosuppressive drugs, leading to the suppression of T lymphocytes (Das et al., 2019; Grän et al., 2020).

Martviset et al. (2020) report another finding of B. coli in urine as the first case occurring in a patient with SLE and lupus nephritis, in Thailand. SLE is a heterogeneous autoimmune disease, which presents an uncontrolled inflammatory reaction and can affect several organs, causing skin rashes, including butterfly-shaped malar rash, oral ulcers, hemolytic anemia and nephritis (Hagberg \& Ronnblom, 2015; Jung \& Suh, 2017).

In SLE, cell instability and immune signals occur, and the balance between tolerance and autoimmunity is lost. It is believed that there is an association in the development of SLE with defects in the removal of apoptotic cell fragments by phagocytic cells, being recognized as potentially immunogenic (Shao \& Cohen, 2011). Antigen-presenting cells (APCs) present recognized auto antigens to $\mathrm{T}$ lymphocytes, leading to the release of pro-inflammatory cytokines, 
such as IL-6, IL-17, IL-18 and TNF- $\alpha$. Plasma cells produce autoantibodies that form immune complexes and damage tissues when deposited. The role of IFN- $\alpha$ is also indicated in the development and pathogenesis of SLE, probably, for example, influencing the suppression of Tregs (Niewold et al., 2010; Lisnevskaia et al., 2014).

Infections are generally reported in patients with SLE, due to the immunosuppressive state generated by the disease itself or by the suppressive drugs used, with greater risks of serious and fulminant manifestations (Braz et al., 2014). In the report in question, the authors suspect that the invasion of the urinary tract occurred due to SLE and worsened after steroid therapy prescription.

Although the large intestine is the most common site of infection by $B$. coli, in certain conditions, extra intestinal sites may harbor the protozoan, as was demonstrated in the review. B. coli is not known to produce toxins, but its ability to cause ulcers in the intestinal mucosa is attributed to the hyaluronidase enzyme (Schuster \& Ramirez-avila, 2008). Although there are no studies demonstrating the mechanisms of extra intestinal dissemination, these probably occur secondary to colonic balantidiasis (Sharma \& Harding, 2003). The protozoan can probably spread to the lungs through the hematological route, lymphatic vessels or through an opening in the diaphragm, and in genitourinary infections, which is believed to occur by direct dissemination of the anal area or by a rectovaginal fistula caused by B. coli (Anargyrou et al., 2003; Vasilakopoulou et al., 2003; Soleimanpour et al., 2015). Regarding the mode of transmission, although direct contact with pigs is recognized, most reports indicate the ingestion of contaminated water or food as the possible infection mechanism.

Few papers have been published demonstrating the mechanisms of the immune response to $B$. coli, and therefore, a number of discoveries in this regard are still pending. Most of the studies include case reports, and do not necessarily elucidate the pathogenesis of the disease and the immunological aspects involved, confirming the need for efforts to elucidate these (Zaman, 1964; Karapetian et al., 2000).

Infection by $B$. coli, although unusual, can present clinical importance in some host immunological conditions, developing a degree of pathogenicity for humans and causing severe fulminant colitis or extra-intestinal disease. The diseases and comorbidities generate imbalance in the innate and adaptive mechanisms of the immune response through persistent systemic inflammation. These circumstances may favor balantidiasis, although this is not restricted to individuals under these conditions, as it is also capable of infection and causing disease in humans with no pre-existing comorbidity. This revision demonstrates that balantidiasis can affect several hosts, emphasizing those with chronic-degenerative diseases or that compromise the immune system, and this manuscript may lead to interest in further research regarding the $B$. coli parasite. 


\section{CONFLICT OF INTEREST}

The authors declare that they have no conflict of interest.

\section{REFERENCES}

1. Adamu H, Wegayehu T, Petros B. High Prevalence of Diarrhoegenic Intestinal Parasite Infections among Non-ART HIV Patients in Fitche. PLoS One 8: 5-9, 2013.

2. Ahmed A, Ijaz M, Ayyub RM, Ghaffar A, Ghauri HN, Aziz MU, Ali S, Altaf M, Awais M, Naveed M, Nawab Y, Javed MU. Balantidium coli in domestic animals: An emerging protozoan pathogen of zoonotic significance. Acta Trop 203: 1-44, 2019.

3. Anargyrou K, Petrikkos GL, Suller MTE, Skiada A, Siakantaris MP, Osuntoyinbo RT, Pangalis G, Vaiopoulos G. Pulmonary Balantidium coli Infection in a Leukemic Patient. Am J Hematol 73: 180-183, 2003.

4. Arcoverde C, Lima RA, Miranda C, Guedes I, Lemos MN. Enteroparasitoses em pacientes infectados pelo vírus da imunodeficiência humana (HIV) atendidos no Hospital das Clínicas da UFPE. Rev Bras Anal Clin 36: 13-17, 2004.

5. Ashwell JD, Lu FWM, Vacchio MS. Glucocorticoids in T cell development and function. Annu Rev Immunol 18: 309-345, 2000.

6. Bachur TPR, Vale JM, Coêlho ICB, Queiroz TRBS de, Chaves C de S. Enteric Parasitic Infections in HIV / AIDS Patients Before and After the Highly Active Antiretroviral Therapy. Brazilian J Infect Dis 12: 115-122, 2008.

7. Basavaraj, Sreekantha, Shepur T, Shashidhar V, Avinash S. Intestinal Parasitic Infestations In HIV Seropositive Children. Int J Pharma Bio Sci 3: 293-299, 2012.

8. Bianchi MV, Mello LS, Wentz MF, Panziera W, Soares JF, Sonne L, Driemeier D, Pavarini SP. Fatal parasite-induced enteritis and typhlocolitis in horses in Southern Brazil. Brazilian J Vet Parasitol 28: 443-450, 2019.

9. Bode C, Bode JC. Effect of alcohol consumption on the gut. Best Pract Res Clin Gastroenterol 17: 575-592, 2003.

10. Bratta D, Quintero B. Reporte de caso. Neumonía adquirida en la comunidad causada por Balantidium coli en un paciente con diabetes mellitus insulino dependiente. MedULA 27: 1-5, 2018.

11. Braz AS, Andrade CAF, Mota LMH, Lima CMBL. Recomendações da Sociedade Brasileira de Reumatologia sobre diagnóstico e tratamento das parasitoses intestinais em pacientes com doenças reumáticas autoimunes. Rev Bras Reumatol 55: 368-380, 2014.

12. Carmeño J, Cuesta I, Uzcátegui O, Páez J, Rivera M, Baliachi N. Balantidium coli in an HIVinfected patient with chronic diarrhea. AIDS 17: 941-942, 2003.

13. Carvalho HA, Villar RC. Radiotherapy and immune response: the systemic effects of a local treatment. Clinics 73: 1-11, 2018.

14. Cerveja BZ, Tucuzo RM, Madureira AC, Langa IA, Buene T, Banze L, Funzamo C, Noormahomed EV. Prevalence of Intestinal Parasites Among HIV Infected and HIV Uninfected Patients Treated at the $1^{\circ}$ de Maio Health Centre in Maputo, Mozambique. EC Microbiol 9: 231-240, 2017.

15. Chovancová Z. Sekundární imunodeficience jako následek chronických onemocnění. Vnitřní Lékařství0 65: 117-124, 2019.

16. Clyti E, Aznar C, Couppie P, Guedj M El, Carme B, Pradinaud R. A case de co-infection par Balantidium coli et VIH en Guyane Française. Bull Soc Pathol Exot 91: 309-311, 1998. 
17. Cristescu B. Balantidium coli and Trichuris trichiura Co-Infection Presented with Lower Gastrointestinal Bleeding - A Case Report. Am J Gastroenterol 102: 421, 2007.

18. Cruz T, López-Giraldo A, Noell G, Casas-Recasens S, Garcia T, Molins L, Otero MJ, Fernandez MA, Agusti A, Faner R. Multi-level immune response network in mild-moderate Chronic Obstructive Pulmonary Disease (COPD). Respir Res 20: 1-9, 2019.

19. Daniluk J, Szuster-Ciesielska A, Kandefer-szerszen M. Serum cytokine levels in alcoholrelated liver cirrhosis. Alcohol 23: 29-34, 2001.

20. Das D, Akhtar S, Kurra S, Gupta S, Sharma A. Emerging role of immune cell network in autoimmune skin disorders: An update on pemphigus, vitiligo and psoriasis. Cytokine Growth Factor Rev 45: 35-44, 2019.

21. Decramer M, Janssens W, Miravitlles M. Chronic obstructive pulmonary disease. Lancet 379: 1341-1351, 2012.

22. Dhawan S, Jain D, Mehta V. Balantidium coli: an unrecognized cause of vertebral osteomyelitis and myelopathy. J Neurosurg Spine 18: 310-313, 2013.

23. Diaz L, Montero A, Gonza M, Vallejo AI, Romeo J, Marcos A. Influence of alcohol consumption on immunological status: a review. Eur J Clin Nutr 56: 50-53, 2002.

24. Dodd LG. Balantidium coli Infestation as a Cause of Acute Appendicitis. J Infect Dis 163: 1392, 1991.

25. Eizirik DL, Pasquali L, Cnop M. Pancreatic $\beta$ - cells in type 1 and type 2 diabetes mellitus: different pathways to failure. Nat Rev Endocrinol 16: 349-362, 2020.

26. Eriso F. Screening for Opportunistic Intestinal Parasites in HIV / AIDS Patients, Attending the Services of Medical Care in Three Different Hospitals, Southern Ethiopia. Afro-Egyptian J Infect Endem Dis 5: 15-23, 2015.

27. Esteghamati A, Khanaliha K, Bokharaei-salim F, Sayyahfar S, Ghaderipour M. Prevalence of Intestinal Parasitic Infection in Cancer, Organ Transplant and Primary Immunodeficiency Patients in Tehran, Iran. Asian Pacific J Cancer Prev 20: 495-501, 2019.

28. Farthing MJG, Kelly P. Protozoal gastrointestinal infections. Medicine (Baltimore) 33: 81-83, 2005.

29. Ferry T, Bouhour D, Monbrison F, Laurent F, Dumouchel-Champagne H, Picot S, Piens MA, Granier P. Severe peritonitis due to Balantidium coli acquired in France. Eur J Clin Microbiol Infect Dis 23: 393-395, 2004.

30. Figueiredo S, Filippis T, Santos U, Caixeta S, Rocha J, Guimarães M. Report on a balantidiasis case in a person living with HIV / aids. Rev Patol Trop 41: 505-509, 2012.

31. Fletcher SM, Stark D, Harkness J, Ellis J. Public Health Perspective Enteric Protozoa in the Developed World : a Public Health Perspective. Clin Microbiol Rev 25: 420-449, 2012.

32. Geerlings SE, Hoepelman AIM. Immune dysfunction in patients with diabetes mellitus. FEMS Immunol Med Microbiol 26: 259-265, 1999.

33. Gerald LB, Bailey WC. Global Initiative for Chronic Obstructive Lung Disease. J Cardiopulm Rehabil 22: 234-244, 2002.

34. Gonçalves RP, Maia DP, Custódio RKA, Machado RPG, Duarte FB, Silva LB. Avaliação do perfil hematológico de pacientes com leucemia linfocítica crônica (LLC-B) em um hemocentro estadual. Rev Bras Hematolologia e Hemoter 31: 228-234, 2009.

35. Gonzalez-Quintela A, Dominguez-Santalla MJ, Perez LF, Vidal C, Lojo S, Barrio E. Short communication influence of acute alcohol intake and alcohol withdrawal on circulating levels of IL-6, IL-8, IL-10 AND IL-12. Cytokine 12: 1437-1440, 2000.

36. Grän F, Kerstan A, Serfling E, Goebeler M. Current Developments in the Immunology of Psoriasis. Yale J Biol Med 93: 97-110, 2020. 
37. Granier P. Severe peritonitis due to Balantidium coli acquired in France. $J$ Clin Microbiol Infect Dis 23: 393-395, 2004.

38. Hagberg N, Ronnblom L. Systemic Lupus Erythematosus - A Disease with A Dysregulated Type I Interferon System. Scand J Immunol 3: 199-207, 2015.

39. Haller H, Strauer BE. Niereninsuffizienz. Internist (Berl) 53: 789-790, 2012.

40. Hattab Y, Alhassan S, Balaan M. Chronic Obstructive Pulmonary Disease. Crit Care Nurs $Q$ 39: 124-130, 2016.

41. Hechenbleikner EM, Mcquade JA. Parasitic Colitis. Clin Colon Rectal Surg 28: 79-86, 2015.

42. Hernández F, Argüello AP, Rivera P, Jiménez E. Balantídium coli (Vestibuliferida: Balantidiidae): The persistence of an old problem. Rev Biol Trop 41: 149-151, 1993.

43. Ikpeama O, Ochayi A, Houmsou R. Intestinal Parasites among HIV / AIDS Patients on ART Attending Specialist Hospital, Sokoto State, Nigeria. Sokoto J Med Lab Sci 1: 117-126, 2016.

44. Ilonen J, Lempainen J, Veijola R. The heterogeneous pathogenesis of type 1 diabetes mellitus. Nat Rev Endocrinol 15: 635-650, 2019.

45. Janssen S, Hermans S, Knap M, Moekotte A, Rossatanga EG, Adegnika AA, Bélard S, Hänscheid T, Grobusch MP. Impact of Anti-Retroviral Treatment and Cotrimoxazole Prophylaxis on Helminth Infections in HIV-Infected Patients in Lambaréné, Gabon. Plos Negleted Trop Dis 9: 1-14, 2015.

46. Jeske S, Bianchi TF, Moura MQ, Baccega B, Pinto NB, Berne MEA, Villela MM. Intestinal parasites in cancer patients in the South of Brazil. Brazilian J Biol 78: 574-578, 2018.

47. Jung J, Suh C. Infection in systemic lupus erythematosus, similarities, and differences with lupus flare. Korean J Intern Med 32: 429-438, 2017.

48. Kapur P, Das AK, Kapur PR, Dudeja M. Balantidium coli liver abscess: first case report from India. J Parasit Dis 40: 138-140, 2016.

49. Karapetian EA, Isaakian ZS, Zavgorodniaia AM. The importance of cellular immunity factors in the pathogenesis of experimental balantidiasis. Parazitologiia 12: 323-326, 2000.

50. Karuna T, Khadanga S. A rare case of urinary balantidiasis in an elderly renal failure patient. Trop Parasitol 4: 47-50, 2014.

51. Kaur S, Gupta A. Case Report Urinary balantidiasis: A rare incidental finding in a patient with chronic obstructive pulmonary disease. J Cytol 33: 169-171, 2016.

52. Khanduri A, Chauhan S, Chandola I. Balantidiosis: A Rare Accidental Finding in the Urine of a Patient with Acute Renal Failure. J Clin Diagnostic Res 8: 20-22, 2014.

53. Kumar M, Rajkumari N, Mandal J, Parija SC. A case report of an uncommon parasitic infection of human balantidiasis. Trop Parasitol 6: 82-84, 2016.

54. Kurts C, Panzer U, Anders H, Rees AJ. The immune system and kidney disease: basic concepts and clinical implications. Nat Publ Gr 13: 738-753, 2013.

55. Lisnevskaia L, Murphy G, Isenberg D. Systemic lupus erythematosus. Lancet 384: 1878-1888, 2014.

56. Liyanage P, Sirimanna GMP, Samarasingha S, Silva RD. Co-infection of Strongyloides stercoralis and Balantidium coli in a patient with pemphigus vulgaris. Sri Lanka J Dermatology 15: 49-50, 2011.

57. Mahmoudi MR, Hasani H, Tsiami A, Ashrafi K, Johnson P. Intestinal protozoan and helminthic infections among hemodialysis and cancer patients. Parasitol Res 119: 3053-3059, 2020.

58. Maino A, Garigali G, Grande R, Messa P, Fogazzi G. Urinary balantidiasis: Diagnosis at a glance by urine sediment examination. J Nephrol 23: 732-737, 2010. 
59. Marrero YT. Leucemia linfoide crónica de células B: revisión de sus aspectos etiopatogénicos, moleculares y pronósticos B-cell chronic lymphoid leukemia: a review of its etiopathogenic, molecular and prognostic aspects. Rev Cuba Hematol Inmunol Hemoter 35: 1-14, 2019.

60. Martviset P, Sirisabhabhorn K, Pumpa S, Rhongbutsri P, Taylor A, Taylor WRJ. Urinary balantidiasis in a patient with systemic lupus erythematosus and lupus nephritis: a case report. J Med Case Rep 14: 1-5, 2020.

61. Melchionda V, Harman KE. Pemphigus vulgaris and pemphigus foliaceus: an overview of the clinical presentation, investigations and management. Clin Exp Dermatol 44: 740-746, 2019.

62. Montessori V, Press N, Harris M, Akagi L, Montaner JSG. Adverse effects of antiretroviral therapy for HIV infection. Can Med Assoc J 170: 229-238, 2004.

63. Nakauchi K. The Prevalence of Balantidium coli Infection in Fifty-Six Mammalian Species. $J$ Vet Med Sci 61: 63-65, 1999.

64. Niewold TB, Clark DN, Salloum R, Poole BD. Interferon Alpha in Systemic Lupus Erythematosus. $J$ of Biomedicine Biotechnol 2010: 1-8, 2010.

65. Nilles-Bije ML, Rivera WL. Ultrastructural and molecular characterization of Balantidium coli isolated in the Philippines. Parasitol Res 106: 387-394, 2010.

66. Nissapatorn V, Sawangjaroen N. Parasitic infections in HIV infected individuals: Diagnostic \& therapeutic challenges. Indian J Med Res 134: 878-897, 2011.

67. Oteng-Seifah E. The prevalence of intestinal parasitic infection and their association with the T-cell CD4+ counts of HIV/Aids infected patients in Kumasi. KNUSTSpace Inst Rep Knust 2015: 1-70, 2015.

68. Pamo O, Marcos F, Ruiz J. Balantidiasis: reporte de cuatro casos y revisión de la casuística de los hospitales de Lima. Rev Medica Hered 2: 1-5, 2013.

69. Parija SC, Giri S. Emerging protozoal pathogens in India: How prepared are we to face the threat? Trop Parasitol 2: 13-19, 2012.

70. Pau AK. Antiretroviral Therapy Current Drugs. Infect Dis Clin NA 28: 371-402, 2014.

71. Pinheiro MC, Lima MA. Caso fatal de balantidíase intestinal. Rev Soc Bras Med Trop 24: 173-176, 1991.

72. Pomajbıkova K, Oborník M, Horák A, Klára J, Petrželková KJ, Grim N, Levecke B, Todd A, Mulama M, Kiyang J, Modrý D. Novel Insights into the Genetic Diversity of Balantidium and Balantidium-like Cyst-forming Ciliates. Plos Negleted Dis 7: 1-11, 2013.

73. Ponce-Gordo F, Fonseca-Salamanca F, Martínez-díaz RA. Genetic Heterogeneity in Internal Transcribed Spacer Genes of Balantidium coli (Litostomatea, Ciliophora). Protist 162: 774794, 2011.

74. Ponce-Gordo F, Jirků-Pomajbíková K. Balantidium coli. In: Rose JB e Jiménez-Cisneros B. Water and Sanitation for the 21st Century: Health and Microbiological Aspects of Excreta and Wastewater Management (Global Water Pathogen Project). Part 3: Specific Excreted Pathogens: Environmental and Epidemiology Aspects - Section 3: Protists), Michigan State University: EUA, 2017. 44p.

75. Proal AD, Marshall TG. Re-framing the Theory of Autoimmunity in the Era of the Microbiome: Persistent Pathogens, Autoantibodies, and Molecular Mimicry. Discov Med 25: 299-308, 2018.

76. Qamar N, Castano D, Patt C, Chu T, Cottrell J. Meta-analysis of alcohol induced gut dysbiosis and the resulting behavioral impact. Behav Brain Res 376: 1-8, 2019.

77. Rabe KF, Watz H. Seminar: Chronic obstructive pulmonary disease. Lancet 389: 1931-1940, 2017.

78. Rogers BB. Overview of Non-hodgkin's Lymphoma. Semin Oncol Nurs 22: 67-72, 2006.

79. Romeo J, Warnberg J, Ascensión M. Drinking pattern and socio-cultural aspects on immune response: an overview. Proc Nut Soc 69: 341-346, 2010. 
80. Saadat YR, Hejazian M, Bastami M, Mahdi S, Khatibi H. The role of microbiota in the pathogenesis of lupus: Does it impact lupus nephritis? Pharmacol Res 139: 191-198, 2018.

81. Sawada NO, Nicolussi AC, Okino L, Cardozo FMC, Zago MMF. Quality of life evaluation in cancer patients to submitted chemotherapy. Rev Esc Enferm USP 43: 578-584, 2009.

82. Schuster FL, Ramirez-Avila L. Current World Status of Balantidium coli. Clin Microbiol Rev 21: 626-638, 2008.

83. Schuster FL, Visvesvara GS. Amebae and ciliated protozoa as causal agents of waterborne zoonotic disease. Vet Parasitol 126: 91-120, 2004.

84. Shao W, Cohen PL. Disturbances of apoptotic cell clearance in systemic lupus erythematosus. Arthritis Res Ther 13: 1-7, 2011.

85. Sharma S, Harding G. Necrotizing lung infection caused by the protozoan Balantidium coli. Can J Infect Dis 14: 163-166, 2003.

86. Silva LP, Márcio R. Parasitos e comensais intestinais em pacientes neoplásicos submetidos à quimioterapia. Biosci J 27: 170-177, 2011.

87. Solaymani-Mohammadi S, Rezaian M, Anwar MA. Human balantidiasis in Iran: an unresolved enigma? Trends Parasitol 21: 160-161, 2005.

88. Soleimanpour S, Babaei DA, Abdolghayyoum D, Roudi M, Raeisalsadati SS. Case Report Urinary infection due to Balantidium coli: a rare accidental zoonotic disease in an addicted and diabetic young female in Iran. JMM Case Reports 3: 1-4, 2015.

89. Souza HC, Mota MR, Alves AR, Lima FD, Chaves SN, Dantas RAE, Abdelmur SBM, Mota APVS. Analysis of compliance to antiretroviral treatment among patients with HIV/AIDS. Rev Bras Enferm 72: 1295-1303, 2019.

90. Sureshchandra S, Anthony R, Jankeel A, Ligh BJK, Walter NAR, Newman N, Grant KA, Messaoudi I. Dose-dependent effects of chronic alcohol drinking on peripheral immune responses. Sci Rep 9: 1-13, 2019.

91. Tanja P, Yu W, Natasa K. Urinary Balantidiasis: A Rare Incidental Finding in a Patient with Psoriasis. J Antimicrob Agents 4: 3-4, 2018.

92. Taye B, Desta K, Ejigu S, Urge G. The magnitude and risk factors of intestinal parasitic infection in relation to Human Immunodeficiency Virus infection and immune status, at ALERT Hospital, Addis Ababa, Ethiopia. Parasitol Int 63: 550-556, 2014.

93. Tecklenborg J, Clayton D, Siebert S, Coley SM. The role of the immune system in kidney disease. Clin Exp Immunol 192: 142-150, 2018.

94. Toychiev A, Abdujapparov S, Imamov A, Navruzov B, Davis N. Intestinal helminths and protozoan infections in patients with colorectal cancer: prevalence and possible association with cancer pathogenesis. Parasitol Res 117: 3715-3723, 2018.

95. Trejo M, Gullo H, Marzo D, Mastrolillo A, Sarabia E, Nigreli C, Almeida G, Ortega SM. Neumonía por un agente infrecuente en un varón de 65 años. Rev del Tórax Prov Buenos Aires 26: 49-51, 2014.

96. Udeh EO, Goselle ON, D-Popova DD, Abelau M, Popov TV, Jean N, David JS. The prevalence of intestinal protozoans. Sci World J 3: 1-4, 2008.

97. Udeh EO, Obiezue RNN, Okafor FC, Ikele CB, Okoye IC. Gastrointestinal Parasitic Infections and Immunological Status of HIV/AIDS Coinfected Individuals in Nigeria. Ann Glob Heal 85: 1-7, 2019.

98. Vasilakopoulou A, Dimarongona K, Samakovli A, Papadimitris K, Avlami A. Balantidium coli Pneumonia in an Immunocompromised Patient. Scand J Infect Dis 35: 144-146, 2003.

99. Vaziri ND, Madeleine V, Crum A, Norris K. Effect of Uremia on Structure and Function of Immune System. J Ren Nutr 22: 149-156, 2012. 
100. Venugopal SS. Diagnosis and Clinical Features of Pemphigus Vulgaris. Dermatol Clin 29: 373-380, 2011.

101. Weisbord SD, Palevsky PM. Acute Renal Failure in the Intensive Care Unit. Semin Respir Crit Care Med 27: 262-273, 2006.

102. Yazar S, Altuntas F, Sahin I, Atambay M. Dysentery caused by Balantidium coli in a patient with non-Hodgkin's lymphoma from Turkey. World J Gastroenterol 10: 458-459, 2004.

103. Zaman V. Studies on the immobilization reaction in the genus Balantidium. Trans $R$ Soc Trop Med Hyg 58: 255-259, 1964.

104. Zhao W, Li M, Xiong F, Zhang D, Wu S, Zou H, Li W, Wang G. Identification of Intracellular Bacteria in the Ciliate Balantidium ctenopharyngodoni (Ciliophora, Litostomatea). J Eukaryot Microbiol 67: 417-426, 2020. 